\title{
FORM, SPACE, AND ORDER IN AL-MUNAWAR ARABIC VILLAGE PALEMBANG
}

\author{
${ }^{1}$ Meuthia Rizki Fauziah. ${ }^{2}$ Dr. Ir. Hartanto Budiyuwono, M.T. \\ ${ }^{1}$ Student in the Bachelor's (S-1) Study Program in Architecture \\ at Parahyangan Catholic University \\ ${ }^{2}$ Senior lecturer in the Bachelor's (S-1) Study Program in Architecture \\ at Parahyangan Catholic University
}

\begin{abstract}
Arabian came to Indonesia to trade and spread Islam in Indonesia. They came by sea or river. Then they stayed and grew a family with locals on an area. That area became a settlement in a form of a village that known as Arabian Village. One of the famous Arabian Villages is Al-Munawar Arabian Village in Palembang.

Al-Munawar Arabian Village is the oldest village in Palembang. This village is still preserve its relics and culture nowadays. One of its remaining relics is eight buildings that decided as heritage buildings. These 8 buildings have their own unique hundreds of year historical background. Three buildings out of eight buildings are picked as object of research.

These buildings are land house. These houses adapted Palembang architectural style, which is pyramid house. Land house has "kekijing" in front of its house. Kekijing is a floor with $\pm 30-40 \mathrm{~cm}$ terraces. Each step of floor illustrates the depth of faith. The division of land house room follows the division of Islamic residential space. The second building is stone house with Indian architectural style. The wall thickness of this house is $\pm 37 \mathrm{~cm}$. Stone house has an increase of $\pm 60 \mathrm{~cm}$ from ground level. The floor material uses tiles imported directly from Italy. The division of stone house room also follows the division of Islamic residential space. The third building is greenhouse. Greenhouse is a residential home that has changed its function to islamic school with the same shape. This house consists of two floors, the first floor uses brick wall and the second floor uses wooden wall. The division of greenhouse room doesn't follow the division of Islamic residential space because the building is not a residential house anymore.

It's important to study the cultural heritage buildings in this village. Considering the number of villages and traditional buildings that forgotten because of the modernization. Furthermore, there are few abandoned traditional houses and changed its shape and material became more modern.

The purpose of this study is to know the shape, room and the order of the house in Al-Munawar Arabian Village on the Palembang Musi River bank.

This is so that traditional buildings in the village will not extinct and become learning materials for all people.

The method used is qualitative method. If judged based on the purpose of the research is descriptive research. The data collecting technique are literature study, field observation and interview to the head of neighborhood in the village. This research shows that style of a building and the material that used on the objects of research are different. In addition, the division of residential space such as stone house and greenhouses are still using the division of Islamic residential space, while the greenhouse is no longer.
\end{abstract}

Key Words: Arabic village Palembang, Al-Munawar village, form, space and order.

\section{BENTUK, RUANG, DAN TATANAN RUMAH PADA KAMPUNG ARAB AL-MUNAWAR PALEMBANG}

\author{
${ }^{1}$ Meuthia Rizki Fauziah. ${ }^{2}$ Dr. Ir. Hartanto Budiyuwono, M.T. \\ ${ }^{1}$ Mahasiswi S1 Program Studi Arsitektur Universitas Katolik Parahyangan \\ ${ }^{2}$ Dosen Pembimbing S1 Program Studi Arsitektur Universitas Katolik Parahyangan
}

\footnotetext{
${ }^{1}$ Corresponding Author: meuthiarizkifauziah27@gmail.com
} 
Abstrak- Bangsa Arab datang ke Indonesia untuk melakukan perdagangan dan menyebarkan agama Islam di Indonesia. Mereka datang melalui jalur laut maupun sungai. Kemudian mereka menetap dan berkeluarga dengan masyarakat setempat pada suatu kawasan. Kawasan tersebut menjadi suatu permukiman berupa kampung yang saat ini dikenal sebagai kampung Arab. Salah satu kampung Arab yang terkenal adalah Kampung Arab AlMunawar di Kota Palembang.

Kampung Arab Al-Munawar merupakan kampung tertua di Kota Palembang. Pada masa sekarang, kampung ini masih menjaga peninggalan dan kebudayaan kampung. Salah satu peninggalannya yang masih ada hingga saat ini adalah delapan bangunan yang telah ditetapkan menjadi bangunan cagar budaya. Delapan bangunan ini memiliki keunikan latar belakang sejarah yang berbeda-beda dan telah berumur ratusan tahun. Diambil tiga dari delapan bangunan untuk menjadi objek penelitian. Bangunan tersebut adalah rumah darat. Rumah ini mengadaptasi gaya arsitektur Palembang, yaitu rumah limas. Rumah darat memiliki kekijing pada bagian depan rumah. Kekijing adalah lantai yang berundak $\pm 30-40 \mathrm{~cm}$. Setiap undakan lantai menggambarkan tingkatan pendalaman agama. Pembagian ruang rumah darat mengikuti pembagian ruang rumah tinggal Islam. Bangunan kedua adalah rumah batu yang bergaya arsitektur Indis. Rumah ini memiliki ketebalan dinding \pm $37 \mathrm{~cm}$. Rumah batu mengalami kenaikan $\pm 60 \mathrm{~cm}$ dari permukaan tanah. Material lantai menggunakan ubin yang diimpor langsung dari Italia. Pembagian ruang rumah batu juga masih mengikuti pembagian ruang rumah tinggal Islam. Bangunan ketiga adalah rumah kaca. Rumah kaca merupakan rumah tinggal yang telah berganti fungsi menjadi madrasah dengan bentuk yang masih sama. Rumah ini terdiri dari dua lantai, lantai satu menggunakan material dinding bata dan lantai dua menggunakan dinding kayu. Pembagian ruang pada rumah kaca tidak lagi mengikuti pembagian ruang rumah tinggal Islam karena fungsi bangunan bukan lagi rumah tinggal.

Bangunan cagar budaya pada kampung ini penting untuk dipelajari. Hal ini mengingat banyaknya kampung maupun bangunan tradisional yang terlupakan karena perkembangan jaman. Selain itu juga banyak rumah-rumah tradisional yang telah ditinggalkan dan mengalami perubahan bentuk maupun material menjadi lebih modern.

Tujuan studi ini adalah untuk mengetahui bentuk, ruang dan tatanan rumah pada kampung Arab AlMunawar di tepi Sungai Musi Palembang. Hal ini agar bangunan tradisional pada kampung tidak punah dan dapat menjadi bahan pembelajaran untuk semua kalangan.

Metode yang digunakan adalah metode kualitatif. Jika dilihat berdasarkan tujuan penelitiannya merupakan penelitian deskriptif. Teknik pengambilan data yang dilakukan adalah studi literatur, observasi lapangan dan wawancara terhadap ketua RT kampung. Penelitian ini memperlihatkan bahwa gaya bangunan serta material yang digunakan pada objek penelitian berbeda-beda. Selain itu pembagian ruang hunian yaitu rumah batu dan rumah kaca masih menggunakan pembagian ruang rumah tinggal Islam, sedangkan rumah kaca sudah tidak lagi.

Kata Kunci: Kampung Arab, Kampung Al-Munawar Palembang, bentuk, ruang dan tatanan.

\section{PENDAHULUAN}

Kedatangan Bangsa Arab ke Indonesia kebanyakan berasal dari Kota Hadramaut, Yaman. Kedatangan mereka ke Indonesia diperkirakan terjadi sejak abad pertengahan (abad ke-13) dan kebanyakan dari Bangsa Arab yang datang merupakan kaum pria. Mereka datang ke Indonesia melalui jalur laut/ sungai. Hal ini dikarenakan tujuan awal Bangsa Arab datang ke Indonesia ialah untuk melakukan perdagangan dan menyebarkan agama Islam ke Indonesia. Pada masa itu, aktivitas perdagangan banyak dilakukan di sekitar dermaga/ pada area perairan. Kemudian mereka menetap dan berkeluarga dengan masyarakat setempat pada suatu kawasan dan terbentuklah permukiman berupa kampung yang kemudian saat ini dikenal sebagai kampung Arab. Kampung Arab tersebar di berbagai daerah di Indonesia, seperti di Kota Jakarta, Surabaya, Aceh, Yogyakarta, Surakarta, dan kota-kota lainnya.

Kota Palembang juga memiliki beberapa kampung Arab yang tersebar di sepanjang tepi Sungai Musi. Salah satu yang terkenal ialah Kampung Arab Al-Munawar. Kampung ini merupakan Kampung Arab pertama yang ada di Kota Palembang dan terletak di Kelurahan 13 Ulu $^{2}$. Jika dilihat pada masa sekarang, Kampung Arab Al-Munawar tidak terlalu memiliki

\footnotetext{
${ }^{2}$ Winnie, Satya. 2016. Kampung Arab Al-Munawar. http://www.satyawinnie.com/2016/02/kampung-al-munawarrekam-jejak-arab-di-palembang.html. Di akses pada 21 April 2018.
} 
banyak perubahan yang terjadi. Berdasarkan hasil wawancara pada masyarakat kampung yang telah dilakukan, beberapa bangunan-bangunan yang ada merupakan bangunanbangunan yang masih asli dan berdiri sejak 350 tahun yang lalu. Beberapa bangunan seperti rumah limas, rumah batu, rumah kaca, dan bangunan lainnya telah menjadi bangunan cagar budaya di Kota Palembang. Hal ini bertujuan untuk mempertahankan bangunan-bangunan tradisional yang masih tersisa di Kota Palembang. Karena jika dilihat dari fenomena saat ini, kebudayaan arsitektur tradisional lama-kelamaan dapat terlupakan sebagai dampak modernisasi yang terjadi. Banyak rumah-rumah tradisional pada suatu kampung yang telah ditinggalkan dan mengubah bentuk maupun material bangunan menjadi lebih modern, misalnya mengubah material rumah kayu menjadi beton. Hal ini tentu sangat disayangkan, karena bangunan-bangunan tersebut dapat punah. Untuk itu bangunan-bangunan arsitektur tradisional yang masih belum mengalami modernisasi pada Kampung Arab Al-Munawar 13 Ulu Palembang penting untuk dipelajari.

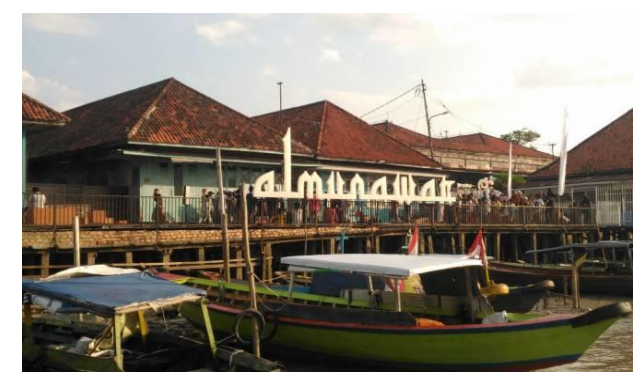

Figur 1. Kampung Arab Al-Munawar Palembang (Sumber: https://sultanpalembang.com. Diakses 21 April 2018)

Dari fenomena yang telah dijabarkan, maka perumusan masalah yang ada pada penelitian ini adalah Bagaimana bentuk, ruang dan tatanan rumah pada Kampung Arab Al-Munawar di tepi Sungai Musi Palembang?. Pertanyaan masalah bertujuan untuk mengetahui bentuk, ruang dan tatanan rumah pada Kampung Arab Al-Munawar. Tujuan tersebut agar dapat mengetahui dan mempelajari lebih dalam mengenai peninggalan bangunan tradisional yang ada di dalam kampung tersebut. Mempelajari bangunan-bangunan yang telah menjadi bangunan cagar budaya yang ada di dalam Kota Palembang.

Manfaat penelitian bagi penulis adalah penulis dapat mempelajari peninggalan kebudayaan arsitektur tradisional yang ada pada Kampung Arab Al-Munawar sebagai kawasan tepi Sungai Musi Palembang. Sedangkan bagi ilmu pengetahuan, dapat memberikan pengetahuan mengenai bentuk, ruang dan tatanan massa pada Kampung Arab Al-Munawar Palembang. Bagi Kampung Arab Al-Munawar sendiri, penelitian ini dapat menjadi suatu data dan dokumentasi mengenai bentuk, ruang dan tatanan massa tradisional yang ada pada kampung mereka sendiri. Dan bagi pemerintah Kota Palembang, penelitian dapat menjadi data dan informasi mengenai arsitektur tradisional yang dapat menjadi pegangan jika akan melakukan revitalisasi pada Kampung Arab di tepi Sungai Musi.

\section{KAJIAN TEORI}

\subsection{BENTUK, RUANG DAN TATANAN KAMPUNG ARAB}

Penelitian ini membahas mengenai bentuk, ruang dan tatanan kampung serta bangunan yang mengadaptasi gata arsitektur Palembang, gaya arsitektur Indis dan gaya arsitektur Arab. Berikut teori yang mendukung penelitian ini: 
Bentuk, Ruang dan Tatanan. Bentuk memiliki wujud dasar yaitu lingkaran, segitiga dan bujur sangkar. Bentuk juga dapat mengalami perubahan baik dengan adisi/ penambahan bentuk maupun dengan substraksi/ pengurangan bentuk. Selain itu terdapt beberapa faktor dalam terciptanya bentuk, yaitu faktor primer dan sekunder. Faktor primer terdiri dari faktor sosial budaya dan faktor sekunder terdiri dari faktor iklim, faktor material, konstruksi, teknologi, faktor tapak, dan faktor agama. Terdapat juga behavior setting dalam desain yang diidentifikasi pda tiga dasar pola ruang yaitu ruang berbatas tetap, ruang berbatas semi tetap dan ruang informal. Selain itu, bentuk dan ruang memiliki berbagai macam konfigurasi dari unsur pembentuk ruang horizontal dan unsur pembentuk ruang vertikal ${ }^{3}$.

Bangunan bergaya arsitektur Palembang, salah satunya adalah rumah limas. Bangunan limas didirikan di atas tiang kayu dan mempunyai lantai yang berundak atau yang biasa disebut kekijing. Setiap undakan atau kekijing tersebut juga berbentuk persegi panjang dengan jumlah dua atau tiga dan terkadang berjumlah empat buah kekijing. Kekijing dapat digunakan untuk acara-acara, dimana setiap undakan kekijing memiliki fungsi:

- Kekijing pertama ditempati oleh kaum kerabat, dan para undangan yang masih muda, biasanya mereka adalah para pekerja dalam acara

- Kekijing kedua ditempati oleh para undangan setengah baya

- Kekijing ketiga maupun keempat ditempati oleh para undangan yang sudah tua dan yang dihormati terutama karena faktor usia

Tipologi dari bangunan limas adalah golongan rumah panggung karena bangunan didirikan dengan mempergunakan tiang. Material yang digunakan biasanya menggunakan jenis kayu yang bermutu baik, contohnya adalah kayu jenis petanang yang mutunya sama dengan kayu unglen/ besi. Kayu ini biasanya digunakan untuk bahan tiang dan bahan lainnya. Sedangkan material dinding, lantai rumah biasanya menggunakan jenis kayu merawan ${ }^{4}$.

Bangunan bergaya arsitektur Arab merupakan rumah tinggal Islam yang menggunakan konsep dekorasi rumah yang tidak menekankan materi dan hal-hal yang berlebihan pada rumah tinggal. Guy T. Petherbridge dalam bukunya yang berjudul Vernacular Architecture The House and Society (1978) menyatakan prinsip-prinsip dasar rumah tinggal masyarakat Islam sebagai berikut:

a. Ruang Publik dan Ruang Privat

Masyarakat Islam memiliki pemilihan yang tegas antara kehidupan sosial dan kehidupan pribadi dalam hubungannya dengan rumah tinggal yang mengacu pada pembagian ruang publik dan ruang privat. Hak dan kewajiban untuk hidup terlindung dalam rumahnya adalah karakteristik dalam budaya Islam. Ruang publik biasanya diperuntukkan bagi ruang laki-laki (birun), sedangkan ruang privat diperuntukkan untuk wanita (anderun).

b. Courtyard

Rumah yang memiliki courtyard adalah rumah yang paling ideal untuk konsep pembagian yang tegas antara kehidupan sosial dan pribadi. Pada bagian depan rumah terlihat jelas, tetapi interior courtyard tetap merupakan tempat keluarga melakukan tugas dan pekerjaannya dengan leluasa.

c. Penggunaan Ruang dalam Rumah Tinggal

Pembagian ruang dalam rumah muslim terbagi atas kepentingan publik dan privat. Di harem, ruang dalam tidak difungsikan secara spesifik. Ruang-ruang ini dapat digunakan untuk banyak keperluan seperti makan, tidur, berekreasi dan untuk tugas-tugas domestik.

\footnotetext{
${ }^{3}$ Francis D.K. Ching, Bentuk, Ruang dan Tatanan, Terj. Nurahma Tresani Hawadi (Jakarta: Erlangga, 2000), 38155.

4 Moh. Alimansyur dkk, Arsitektur Tradisional Daerah Sumatera Selatan, (Bandung: Direktur Jenderal Kebudayaan Departemen Pendidikan dan Budaya, 1990), 26-30.
} 
Penggunaan ruang yang fleksibel dari ruang keluarga terefleksikan dengan tidak adanya perabot-perabot yang tidak praktis seperti lemari makan, meja dan kursi.

Selain itu rumah tinggal keturunan Arab yang masih asli selalu memiliki pintu kecil di pagar belakang yang mengelilingi rumah tersebut. Biasanya di belakang rumah terdapat jalan kecil seperti lorong pada jajaran rumah-rumah tersebut yang berfungsi sebagai jalan wanita menuju ke rumahnya 5 .

Bangunan bergaya arsitektur Indis. Arsitektur Indis sebagai manifestasi dari nilainilai budaya yang berlaku pada zaman itu ditampilkan lewat kualitas bahan, dimensi ruang yang besar, gemerlapnya cahaya, pemilihan perabot, dan seni ukir kualitas tinggi sebagai penghias gedung. Menurut Denys Lombard, sejarah terbentuknya budaya Indis karena didorong oleh kekuasaan Hindia Belanda yang berkehendak menjalankan pemerintahan dengan menyesuaikan diri pada kondisi budaya masyarakat di wilayah kolonialnya (Soekiman (2000)). Untuk itu, bangunan yang bergaya arsitektur Indis atau Indische Architectuur (gaya arsitektur neo-klasik) memiliki karakteristik sebagai berikut: ${ }^{6}$

- Denah simetris, tidak bertingkat/ satu lantai, beratap perisai

- Tembok yang tebal

- Langit-langit yang tinggi

- Terdapat beranda depan dan belakang yang memiliki barisan pilar atau kolom bergaya klasik

- Pilar menjulang ke atas sebagai pendukung atap

- Terdapat gavel atau mahkota di atas beranda depan dan belakang

- Terdapat central room yang berhubungan langsung dengan beranda depan dan belakang, di kiri dan kanannya tempat tidur

- Daerah servis di belakang dan berhubungan dengan bangunan induk.

Pencapaian merupakan suatu pendekatan ke suatu tempat atau bangunan yang jalan masuknya dapat berbeda-beda dengan waktu tempuh yang berbeda-beda pula. Jalan tersebut dapat tegak lurus langsung terhadap muka utama suatu tempat/ bangunan, miring (tersamar), sifat pendekatannya dapat berlawanan dengan apa yang terlihat, atau mungkin menerus sampai ke dalam rangkaian ruang-ruang interior bangunan, sehingga dapat mengaburkan perbedaan antara suasana di dalam dan di luar bangunan. Selain itu juga semua jalur mempunyai titik awal yang melewati ruang-ruang hingga ke tujuan akhir. Sifat konfigurasi jalan mempengaruhi atau sebaliknya dipengaruhi oleh pola organisasi ruang-ruang yang dihubungkannya. Konfigurasi jalur ini dapat berupa linear, radial, spiral, grid maupun jaringan sedangkan hubungan jalur dan ruang dapat berupa melalui ruang-ruang, menembus ruang-ruang dan berakhir dalam ruang. Bentuk ruang sirkulasi dapat berbentuk tertutup, berbentuk terbuka pada satu sisi dan terbuka pada kedua sisi.

Prinsip tatanan dipakai untuk menciptakan tatanan di dalam suatu komposisi arsitektur. Penataan tidak hanya berupa aturan geometrik tetapi lebih pada suatu kondisi di mana setiap bagian dari seluruh komposisi saling berhubungan dengan bagian lain dengan tujuan menghasilkan sesuatu susunan yang harmonis. Prinsip tatanan dapat berupa sumbu, simetri, transformasi, datum, hirarki dan irama.

\footnotetext{
5 Sana Malik dan Benish Mujahid, Perception of House Design in Islam: Experiences from Saudi Arabia and Pakistan, (Pakistan: University of Management and Technology Pakistan, 2016) 4-9.

6 Elvira Putri Ayu, Perpaduan Langgam Arsitektur Rumah Tinggal di Kampung Arab Al-Munawar Palembang, (Bandung: Universitas Katolik Parahyangan, 2011), 14-15.
} 


\section{METODA PENELITIAN}

Jenis Penelitian. Metode yang digunakan pada penyusunan penelitian ini adalah metode kualitatif, yaitu pendekatan yang mengandung makna suatu penggambaran atas data dengan menggunakan kata dan baris kalimat (menekankan pada penjelasan deskriptif pada masalah yang sedang diteliti penulis $)^{7}$. Jika dilihat berdasarkan tujuan pene litiannya merupakan penelitian deskriptif, yaitu penelitian yang bertujuan untuk memberikan penjelasan pada objek penelitian dan umumnya mencari suatu permasalahan yang berdasarkan beberapa indikator pada objek penelitian.

Objek penelitian merupakan Kampung Arab Al-Munawar yang berada di kota Palembang. Ruang lingkup penelitian yang dilakukan adalah analisa bentuk, ruang dan tatanan rumah pada Kampung Arab Al-Munawar di tepi Sungai Musi. Analisa yang dilakukan berfungsi untuk melakukan pendeskripsian pada Kampung Arab Al-Munawar di Palembang di tepi Sungai Musi Palembang.

Teknik Pengumpulan Data. Pengumpulan data yang dilakukan adalah dengan cara observasi atau pengamatan langsung di lapangan untuk melihat kondisi nyata pada objek penelitian. Observasi pada kampung ini dilakukan mulai tanggal 16 hingga 27 April 2018. Selain melakukan observasi, juga dilakukan dokumentasi berupa pengambilan gambar menggunakan kamera (fotografi) dan pengukuran terhadap rumah-rumah yang menjadi objek penelitian. Pengukuran dilakukan dengan menggunakan meteran konvensional (roll meter) juga menggunakan meteran laser. Pengukuran dilakukan untuk mendapatkan besaran luas ruangan pada rumah-rumah yang menjadi objek penelitian. Hasil dari pengukuran tersebut diolah lagi dengan menggunakan software berupa autocad untuk menghasilkan denah dan software sketchup untuk menghasilkan 3D objek penelitian tersebut. Pada saat melakukan observasi dan pengukuran pada rumah-rumah yang menjadi objek penelitian, tidak semua ruangan dapat dimasuki. Selain itu juga waktu yang diberikan untuk memasuki rumah tersebut dibatasi sehingga, beberapa ruangan di dalam rumah tidak dapat diukur dan hanya mengikuti luasan yang ada. Data yang ada juga didapat dari Universitas Katolik Musi Charitas (UNISKA) Palembang untuk melengkapi data-data yang sulit di dapat.

Teknik pengumpulan data lainnya dengan melakukan studi literatur. Studi literature yang dilakukan mengenai bentuk, ruang dan tatanan, arsitektur Palembang, arsitektur Arab, arsitektur Indis serta jurnal-jurnal yang berhubungan dengan Kampung Arab Al-Munawar Palembang. Selain itu juga dilakukan wawancara dengan ketua RT kampung yaitu Pak Muhammad Al-Munawar. Wawancara yang dilakukan untuk mengetahui sejarah serta aktivitas yang ada pada kampung tersebut.

Teknik Analisis Data. Dari hasil observasi lapangan di dapat fenomena untuk pembahasan penelitian. Kemudian pembahasan penelitian juga dibantu oleh studi literatur yang telah dilakukan serta informasi yang di dapat dari hasil wawancara. Setelah semua itu, analisis data dilakukan dengan memproses data-data yang telah dikumpulkan. Pemrosesan data yang dilakukan untuk mendeskripsikan dan memaparkan bagaimana bentuk, ruang dan tatanan rumah pada Kampung Arab Al-Munawar tersebut.

\section{ANALISA}

Massa pada Kampung Arab Al-Munawar di wakilkan pada tiga objek penelitian. Tiga objek penelitian diambil berdasarkan pertimbangan keunikan latar belakang sejarah dari masing-masing bangunan. Objek penelitian dibagi menjadi hunian dan non hunian. Yang

\footnotetext{
7 Ibnudin. 2017. Metode Penelitian | Pengertian, Tujuan, Macam, dan Metodologi Penelitian. https://ibnudin.net/metode-penelitian-metodologi-penelitian. Diakses pada 5 Februari 2018.
} 
termasuk hunian adalah rumah darat dan rumah batu, sedangkan yang termasuk non hunian adalah rumah kaca yang berfungsi sebagai madrasah.

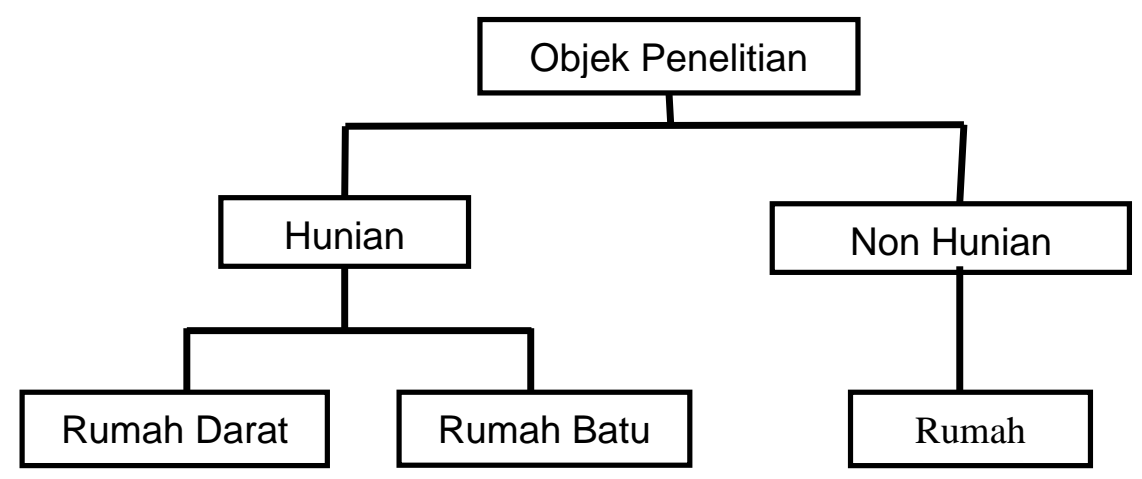

Diagram 1. Pembagian Objek Penelitian

Massa hunian Rumah Darat merupakan rumah kedua tertua di kampung Arab ini memiliki gaya arsitektur tradisional Palembang yaitu rumah limas dengan lantai bertingkat/ kekijing. Rumah darat termasuk tipe rumah panggung. Rumah ini disebut rumah darat karena lokasinya yang cukup jauh dari Sungai Musi.

Bentuk dasar dari rumah darat adalah persegi panjang. Bentuk ini kemudian mengalami substraksi atau pengurangan bentuk namun tidak menghilangkan identitas bentuk dasar persegi panjangnya.
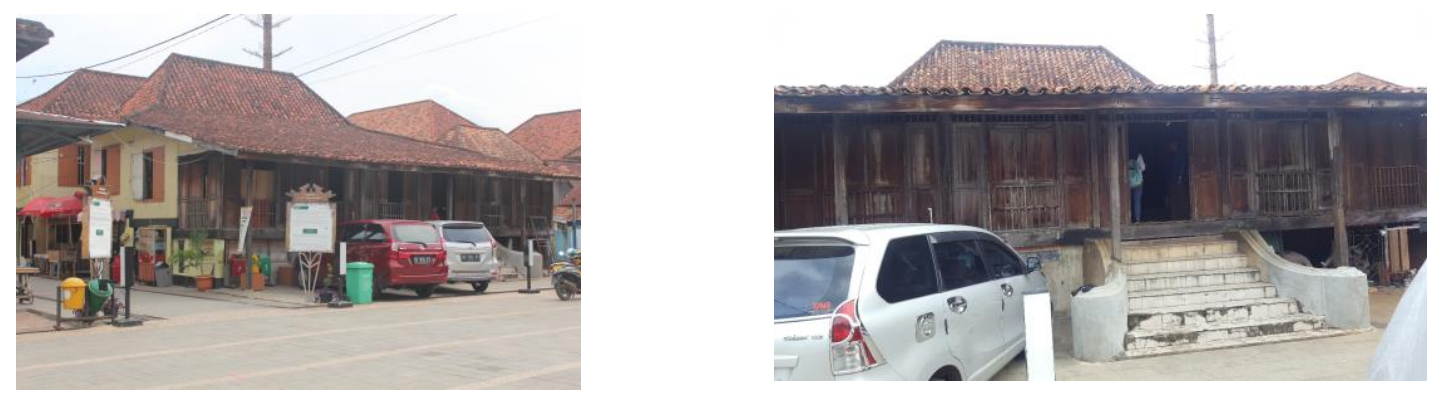

Figur 2. Rumah Darat

Faktor primer dari terciptanya bentuk adalah faktor sosial budaya. Rumah darat memiliki gaya bangunan yang mengadaptasi gaya arsitektur rumah limas Palembang. Dapat dikatakan bahwa pada saat pendiri Kampung Al-Munawar (Habib Abdurrahman Al Munawar) datang ke Palembang, beliau tidak membawa gaya arsitektur dari Negara asalnya yaitu Negara Yaman. Bangsa Al-Munawar datang ke Palembang hanya membawa ilmu perdagangan, ilmu agama dan budaya kehidupan Islam mereka. Hal ini karena bangsa AlMunawar dari awal hijrah hingga ke Kota Palembang hanya untuk menyebarkan agama Islam melalui jalur perdagangan.

Selain dari faktor sosial budaya, rumah darat juga dipengaruhi oleh faktor iklim. Meskipun faktor iklim termasuk faktor sekunder dari faktor terciptanya suatu bentuk, akan tetapi faktor ini cukup mempengruhi Bangsa Al-Munawar untuk memilih bentuk hunian mereka. Pada masa-masa awal Bangsa Al-Munawar menetap di Palembang tepatnya di 13 Ilir, kondisi permukaan air di Sungai Musi masih cukup tinggi. Rumah limas yang masih 
termasuk ke dalam tipologi bangunan rumah panggung merupakan rumah yang cukup baik dan tahan akan iklim pada kondisi saat itu.

Selain itu faktor material pada bangunan mempengaruhi kekokohan bangunan rumah darat. Penggunaan material kayu ulin dengan mutu kayu yang sangat baik dan sifat material kayu yang tahan terhadap air, cuaca panas dan hujan membuat rumah darat dapat berdiri hingga ratusan tahun. Terbukti, hingga saat ini rumah darat tidak terlalu banyak melakukan renovasi meskipun umur dari rumah ini sudah lebih dari 350 tahun.

Behavior setting rumah darat yang mengikuti dasar pola ruang pada rumah darat adalah ruang berbatas tetap (Fixed Features Space). Pembatas ruang berupa dinding-dinding kayu yang melingkupi bangunan ini relatif tetap, maksudnya adalah pembatas ruang tidak mudah untuk digeser atau dipindahkan.

Unsur pembentuk ruang secara vertikal pada rumah darat yaitu empat bidang tertutup berupa dinding kayu pada bangunan. Unsur pembentuk ruang secara horizontal pada rumah darat yaitu bidang dasar yang diangkat. Rumah darat merupakan rumah limas yang berjenis panggung. Pada rumah darat, kenaikan bangunan dari tanah sekitar 1.26 meter $^{2}$.

Pencapaian ke rumah darat melalui pintu masuk. Pintu masuk diletakkan terpusat pada bidang depan bangunan, namun tidak terlalu berada di tengan bidang depan rumah darat. Pintu masuk ini dibuat rata untuk menjaga kontinuitas permukaan dinding. Selain itu juga terdapat pintu masuk pada bagian samping rumah tinggal. Pintu ini bukanlah pintu utama dari rumah darat. Fungsi pintu pada bagian samping rumah adalah sebagai jalan perempuan untuk menuju ke dalam rumahnya. Hal ini untuk menghindari kaum wanita bertemu laki-laki yang bukan muhrimnya apabila ruang tamu/ teras depan rumah sedang kedatangan tamu laki-laki yang bukan muhrimnya.

Konfigurasi jalur pada rumah darat adalah linear. Konfigurasi jalur linear ini menjadi pengorganisir untuk ruang-ruang yang ada di dalam bangunan. Sedangkan hubungan jalur dan ruang adalah menembus ruang-ruang. Hubungan jalur dan ruang ini menimbulkan pola-pola istirahat dan gerak pada rumah darat. Bentuk ruang sirkulasi pada rumah darat adalah tertutup.

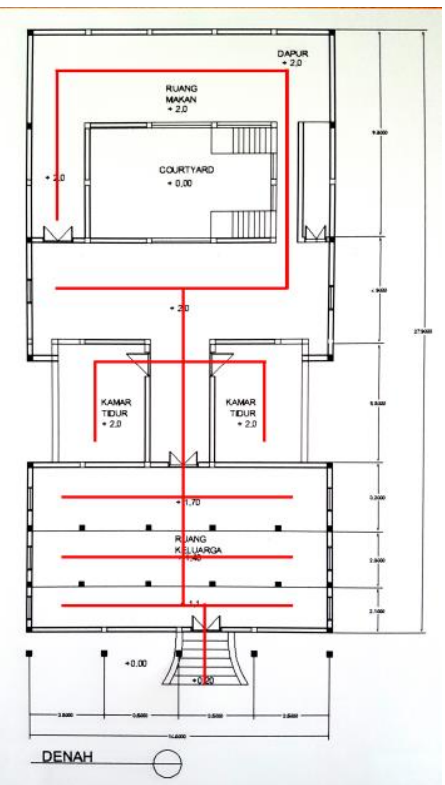

Figur 3. Jalur Sirkulasi Rumah Darat

Tatanan Rumah Darat. Rumah darat memiliki sumbu tengah pada bangunan. Sumbu ini membaginya menjadi dua bagian, area kiri dan area kanan. Sehingga membuat 
rumah darat menjadi simetris. Hirarki pada bangunan rumah darat adalah kekijing (lantai yang berundak setinggi $30 \mathrm{~cm}$ ) pada bagian depan bangunan. Kekijing memiliki dimensi ruang yang cukup besar dibandingkan dengan ruang lain pada bangunan. Bagian rumah kekijing juga sering digunakan warga untuk acara-acara di dalam kampung, seperti untuk pengajian, acara pembelajaran untuk umum, dan lain sebagainya. Letaknya yang berada pada bagian depan bangunan membuatnya mudah di akses. Kekijing digunakan hampir setiap hari dalam seminggu. Dan jendela-jendela pada bagian samping bangunan memiliki irama yang terus di repetisisi atau pengulangan yang berpola pada dinding samping rumah. Pengulanagan ini dilakukan secara linear. Repetisi jendela membentuk karakteristik visual pada rumah darat.

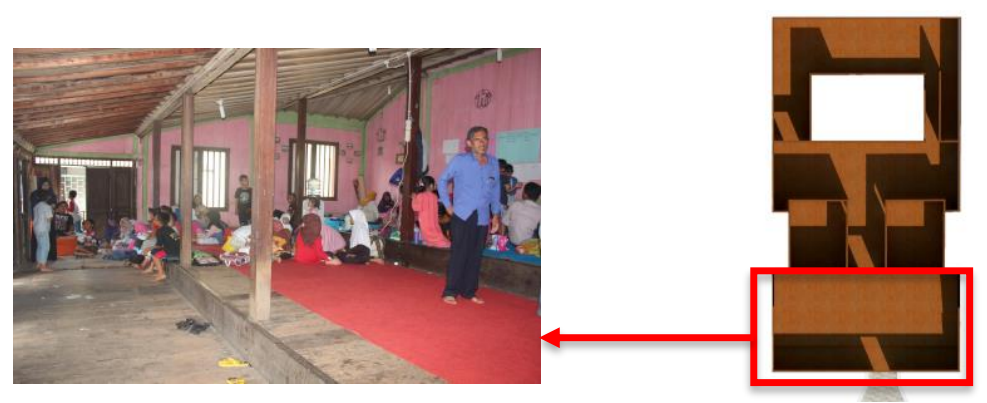

Figur 4. Kekijing pada Rumah Darat

Pembagian ruang rumah darat berdasarkan rumah tinggal Islam. Pembagian ruang didasarkan pada kehidupan sosial dan kehidupan pribadi pemilik rumah yang mengacu pada pembagian ruang publik dan ruang. Ruang privat lebih diperuntukkan untuk kaum wanita dan ruang publik lebih diperuntukkan untuk kaum laki-laki. Sehingga pembagian ruang rumah darat dibedakan menjadi dua zona, yaitu zona privat (anderun) dan zona publik (birun). Pada zona birun terdiri dari ruang tamu yang merupakan area kekijing pada bangunan. Kekijing dapat digunakan sebagai tempat menerima tamu dan tempat untuk menampung acara-acara khusus yang diadakan di dalam kampung. Zona anderun terdiri dari ruang tidur, ruang keluarga, ruang makan dan dapur. Zona ini bersifat lebih privat bagi penghuni rumah. Rumah darat memiliki Courtyard di dalam bangunan dan merupakan ciri rumah tinggal Bangsa Arab yang memiliki fungsi utama untuk mengurangi pengaruh iklim di wilayah yang panas dan gersang. Fungsi lain dari courtyard adalah melindungi perempuan dalam melakukan aktivitas di dalam rumah tanpa terlihat oleh orang luar terutama laki-laki yang bukan muhrimnya.

Massa hunian rumah batu merupakan rumah ketiga tertua yang ada di dalam Kampung Arab Al-Munawar. Rumah ini didirikan pada tahun 1821-an dan merupakan rumah pertama yang bergaya arsitektur Indis dengan hanya memiliki satu lantai di dalam kampung. Rumah ini disebut rumah batu karena dinding rumah ini memiliki tebal $37 \mathrm{~cm}$.
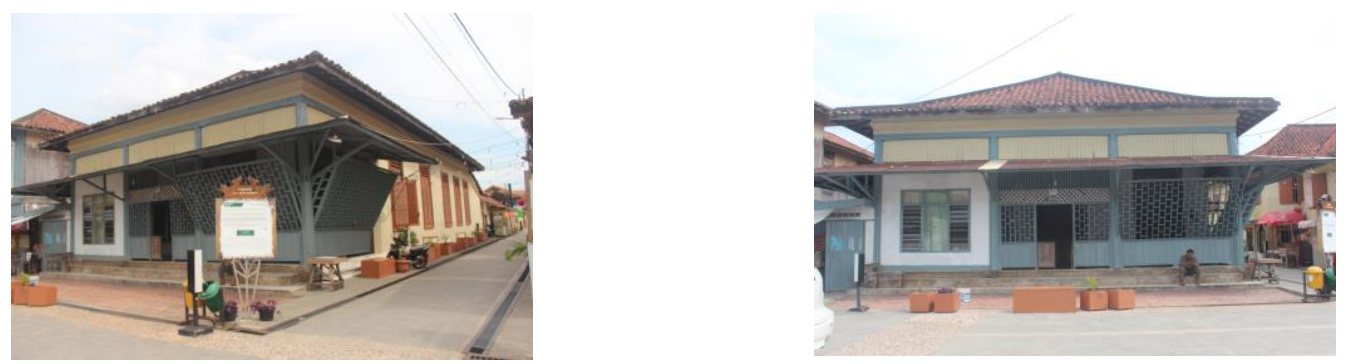

Figur 5. Rumah Batu 
Bentuk dasar rumah batu. Rumah batu memiliki bentuk dasar persegi panjang. Bentuk ini kemudian mengalami penghilangan bentuk/ substraksi pada bagian dalam bentuk dasar persegi panjang. Akan tetapi, substraksi yang dilakukan tidak menghilangkan bentuk dasar dari rumah batu tersebut.

Faktor terciptanya bentuk rumah batu. Faktor sosial budaya yang dimaksud adalah gaya bangunan yang menggunakan arsitektur Indis. Hal ini dilihat dari denah bangunan yang cukup simetris, ukuran bukaan baik jendela maupun pintu yang besar serta dinding bangunan yang terbuat dari batu dan cukup tebal (sekitar $37 \mathrm{~cm}$ ). Selain itu juga terdapat faktor material. Rumah ini menggunakan material batu dengan ketebalan $37 \mathrm{~cm}$ pada dinding rumah. Dinding yang tebal membuat rumah batu dapat berdiri kokoh meski telah berusia ratusan tahun dan dapat menjadi benteng perlindungan bagi warga kampung pada saat terjadinya perang lima hari lima malam di Kota Palembang.

Behavior setting dalam rumah batu berdasarkan dasar pola ruang rumah batu adalah ruang berbatas tetap dan ruang berbatas tidak tetap. Pembatas ruang tetap berupa dinding batu dan pembatas ruang tidak tetap berupa dinding partisi. Ruang yang dibatasi oleh dinding partisi merupakan ruang tambahan di dalam bangunan. Sedangkan ruang yang dibatasi oleh dinding batu merupakan ruang asli yang belum mengalami perubahan. Penambahan ruang dilakukan karena adanya penambahan kebutuhan ruang berupa kamar tidur di dalam rumah batu.

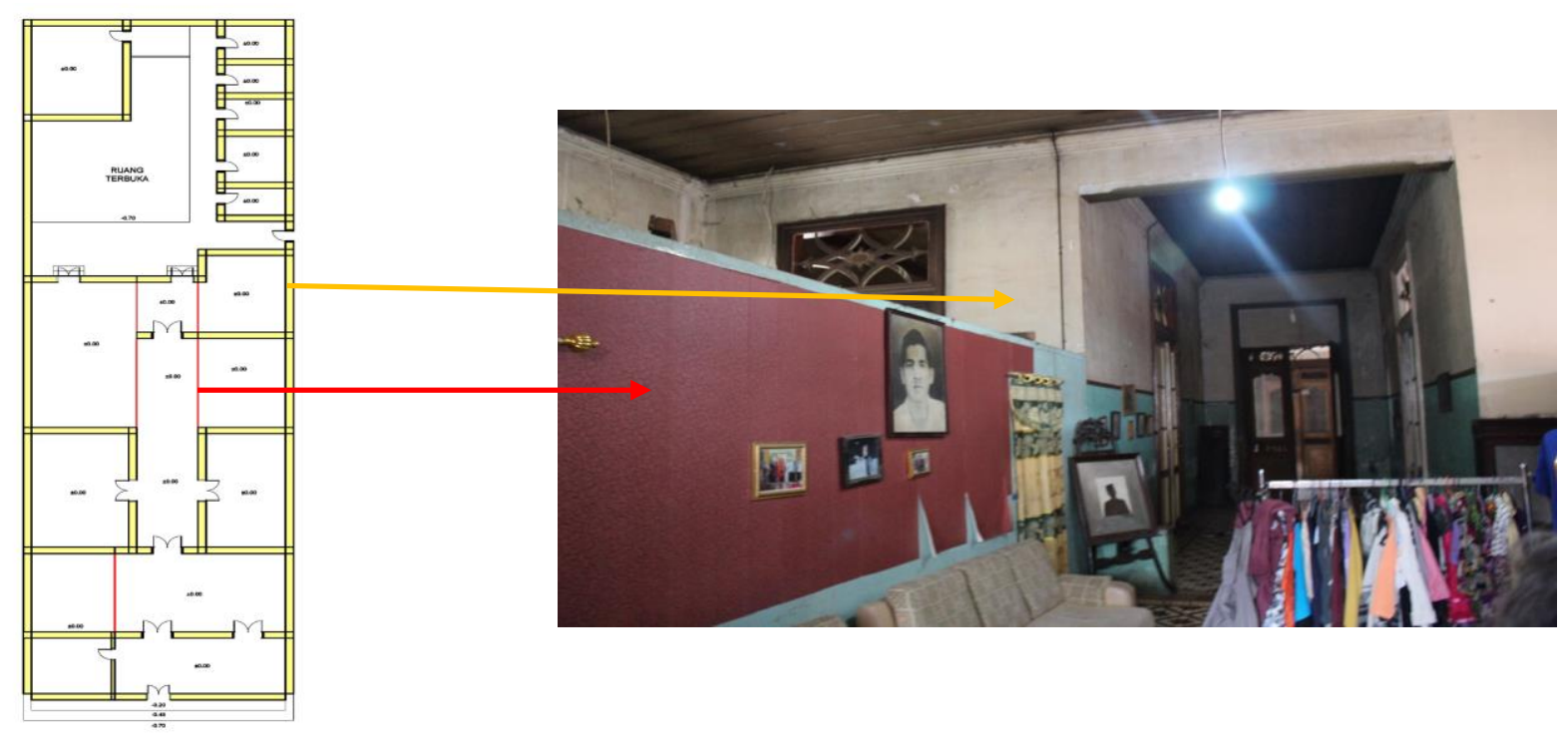

Figur 6. Pembatas Ruang Tetap dan Tidak Tetap Rumah Batu 


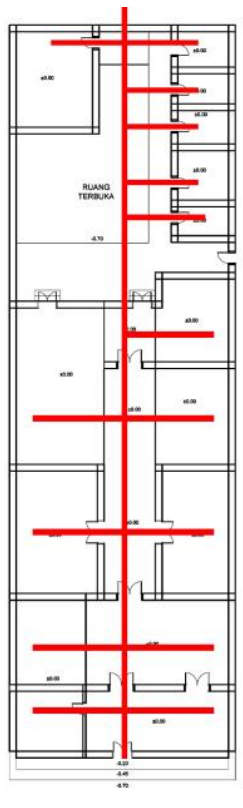

moromase $\ominus$

Figur 7. Jalur Sirkulasi Rumah Batu

Unsur pembentuk ruang. Secara vertikal rumah batu adalah empat bidang tertutup. Empat bidang tertutup tersebut berupa dinding batu. Sedangkan secara horizontal adalah bidang dasar yang diangkat. Rumah batu merupakan rumah pertama di dalam kampung Arab Al-Munawar yang menggunakan pondasi batu dan di angkat dari permukaan tanah. Bangunan rumah batu mengalami kenaikan $60 \mathrm{~cm}$ dari permukaan tanah. Selain itu, atap juga merupakan unsur pembentuk ruang secara horizontal yang termmasuk kategori bidang atas.

Pencapaian ke rumah batu melalui pintu masuk. Pintu masuk pada rumah batu diletakkan terpusat pada bidang depan bangunan. Pintu masuk ini dibuat rata untuk menjaga kontinuitas permukaan dinding bangunan. Sedangkan, Pintu masuk alternatif pada rumah batu berada di samping bangunan. Pada masa sekarang, pintu alternatif lebih sering digunakan dibandingkan pintu utama rumah batu. Sedangkan pintu utama lebih sering digunakan apabila lebaran Idul Fitri dan lebaran Idul Adha serta apabila ada tamu yang berkunjung saja.

Konfigurasi jalur rumah batu adalah linear. Konfigurasi ini membantu dalam pengorganisir ruang-ruang di dalam rumah batu. Selain itu, rumah batu memiliki hubungan jalur dan ruang adalah menembus ruang-ruang dan memiliki bentuk ruang sirkulsi tertutup.

Tatanan rumah batu. Rumah batu memiliki sumbu tengah pada bangunan. Sumbu ini kemudian yang membuat bangunan menjadi simetris dan memberikan keseimbangan dalam bentuknya. Pembagian ruang di dalam bangunan pada awalnya juga ikut menjadi simetris. Akan tetapi dikarenakan ada beberapa penambahan ruang, maka pembagian ruang pada rumah batu tidak terlalu simetris lagi. Selain itu, rumah batu memiliki teras pada bagian depan bangunan. Teras ini bersifat publik dan biasa dijadikan sebagai tempat duduk-duduk bagi pengunjung kampung maupun warga Kampung Al-Munawar itu sendiri. Jika dilihat dari kegunaan ruang pada rumah batu, teras luar lebih sering digunakan sebagai tempat bersosialisasi antar-warga maupun pengunjung kampung. Sehingga teras luar dapat menjadi hirarki rumah batu, karena kegunaan ruang yang lebih bersifat publik dan dapat melibatkan banyak orang serta dapat terjadi banyak interaksi pada ruang tersebut. Dan seperti rumah darat, jendela pada rumah batu mengalami repetisi atau pengulangan yang berpola pada 
dinding samping rumah. Pengulangan bentuk jendela dilakukan secara linear. Repetisi jendela ini kemudian membentuk karakteristik visual pada bangunan.

Pembagian ruang rumah batu. Sama halnya dengan rumah darat, rumah batu juga memiliki pembagian ruang seperti rumah tinggal Islam. Pembagian ruang yang didasarkan pada kehidupan sosial dan pribadi pemilik rumah. Sehingga pembagian rumah batu lebih mengacu kepada zona publik (birun) dan zona privat (anderun). Pada pembagian ruang rumah batu pada awalnya mengacu pada pembagian ruang rumah tinggal Indis. Yaitu adanya ruang utama yang berhubungan langsung dengan teras luar yang berada di bagian depan rumah dengan teras belakang dekat dengan courtyard. Sisi kiri dan sisi kanan dari ruang utama merupakan ruang-ruang yang digunakan sebagai kamar tidur serta area servis di letakkan pada bagian belakang bangunan namun tetap berhubungan dengan massa induk. Dan zona birun terdiri dari teras luar dan ruang tamu, sedangkan zona anderun terdiri dari ruang tidur, gudang, butik baju, dapur, musholla, tempat wudhu dan courtyard.

Massa non-hunian rumah kaca telah berganti fungsi dari rumah tinggal menjadi madrasah. Gaya bangunan rumah kaca merupakan campuran gaya arsitektur tradisional Palembang yaitu rumah panggung dengan gaya arsitektur Indis (gaya arsitektur peninggalan Kolonial Belanda). Rumah kaca terdiri dari dua lantai, lantai satu menggunakan material bata dan lantai dua bermaterial kayu. Bangunan dua lantai ini seperti mengambil gaya arsitektur Palembang, yaitu rumah panggung. Seperti rumah tinggal lainnya di kampung, rumah kaca juga memiliki courtyard pada bagian belakang rumah yang mencirikan sebagai rumah tinggal Islam. Rumah ini disebut rumah kaca karena pada lantai dua banyak terdapat kaca.
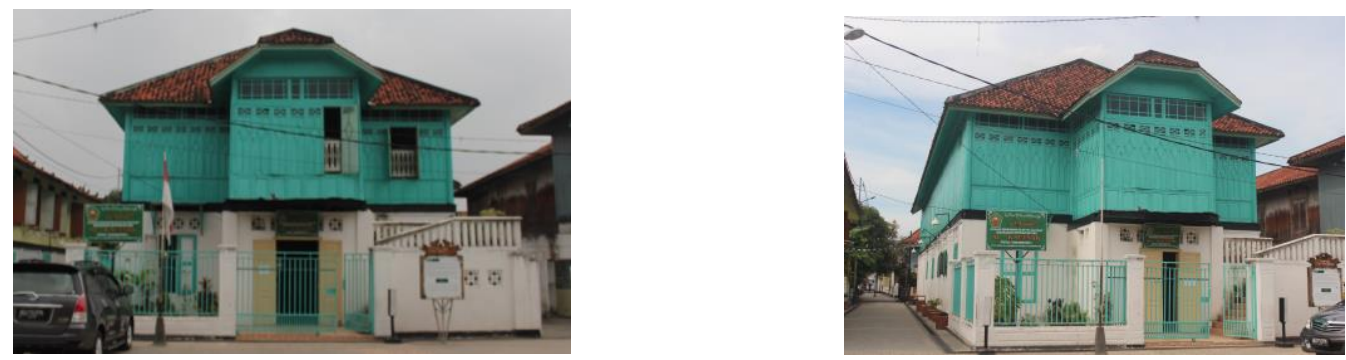

Figur 8. Rumah Kaca

Bentuk dasar rumah kaca adalah persegi panjang, Bentuk ini mengalami penambahan bentuk/ adisi pada bagian depan, bagian belakang dan bagian samping rumah kaca. Penambahan bentuk terjadi karena adanya penambahan kebutuhan ruang oleh pemilik rumah. Namun, bentuk ini tetap merupakan bentuk asli rumah kaca.

Faktor terciptanya bentuk. Faktor sosial budaya, hal ini karena rumah kaca mengadaptasi gaya arsitektur Indis dan arsitektur Palembang. Sedangkan faktor material bangunan menggunakan dua material yang berbeda pada tiap lantainya. Lantai pertama menggunakan material batu bata dan beton, sedangkan lantai kedua menggunakan material kayu. Penggunaan material dinding batu bata dan beton pada lantai bawah membuat rumah ini dapat berdiri kokoh hingga saat ini. Karena lantai bawah menjadi penompang untuk ruang-ruang pada lantai atas yang ber dinding kayu. Material kayu yang digunakan bermutu sangat baik, sehingga masih dapat bertahan sampai sekarang meskipun bangunan telah berumur ratusan tahun. Serta penggunaan material batu bata pada lantai satu menggunakan material batu bata dengan mutu yang baik. Akan tetapi pada saat ditempati oleh penghuni pertama rumah ini, lantai satu merupakan gudang garam. Sehingga, dinding pada beberapa titik tidak dapat di cat maupun di plester karena tingginya kandungan garam pada dinding tersebut. Namun hal ini tidak mengurangi ke kokohan bangunan rumah kaca. 
Behavior setting dalam rumah darat berdasarkan dasar pola ruang pada rumah kaca adalah ruang berbatas tetap (Fixed Features Space). Jika dilihat pada lantai satu, pembatas ruang yang ada adalah dinding-dinding bata yang di cat berwarna putih polos. Sedangkan pada lantai dua, pembatas ruang yang ada adalah dinding-dinding kayu yang di cat dengan warna hijau toska.

Unsur pembentuk ruang. Secara vertikal, unsur pembentuk ruang adalah empat bidang tertutup. Empat bidang tertutup ini berupa dinding bata pada lantai satu dan dinding kayu pada lantai dua. Sedangkan secara horizontal, adanya bidang dasar yang diangkat. Bidang dasar yang diangkat itu adalah lantai dua dari rumah kaca, yang merupakan permukaan vertikal dengan bermaterialkan kayu dan dicat warna hijau toska.

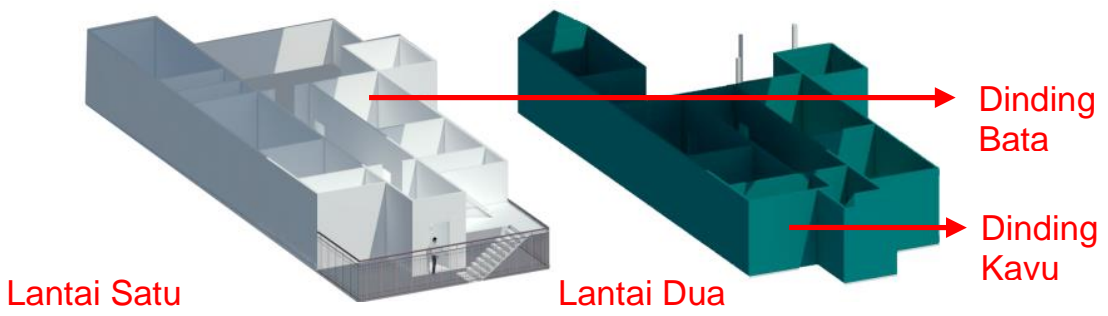

Figur 9. Unsur Pembentuk Ruang Secara Vertikal pada Rumah Kaca

Pencapaian ke rumah kaca melalui pintu masuk. Pintu masuk pada rumah kaca dibuat menjorok keluar. Hal ini yang membuat pintu menjadi ruang transisi dari ruang luar ke ruang dalam. Perletakkan pintu masuk pada bangunan merupakan perletakkan yang terpusat. Seperti pada bangunan-bangunan hunian lainnya di dalam Kampung Arab Al-Munawar, rumah kaca juga memiliki akses pintu alternatif selain pintu masuk utama pada bagian depan bangunan. Hal ini dikarenakan fungsi bangunan rumah kaca sebelum menjadi madrasah adalah rumah tinggal. Pintu masuk alternatif ini sebelumnya diperuntukkan bagi kaum perempuan yang tinggal di dalam bangunan.

Konfigurasi jalur pada rumah kaca adalah linear. Konfigurasi ini berfungsi sebagai pengorganisir ruang-ruang yang ada di dalam bangunan. Selain itu, hubungan jalur dan ruang pada rumah kaca adalah melalui ruang-ruang. Hubungan jalur dan ruang ini membuat sirkulasi menjadi lebih fleksibel dan menyatukan ruang-ruang di dalam bangunan. Sedangkan bentuk ruang sirkulasi di dalam rumah kaca adalah tertutup. 

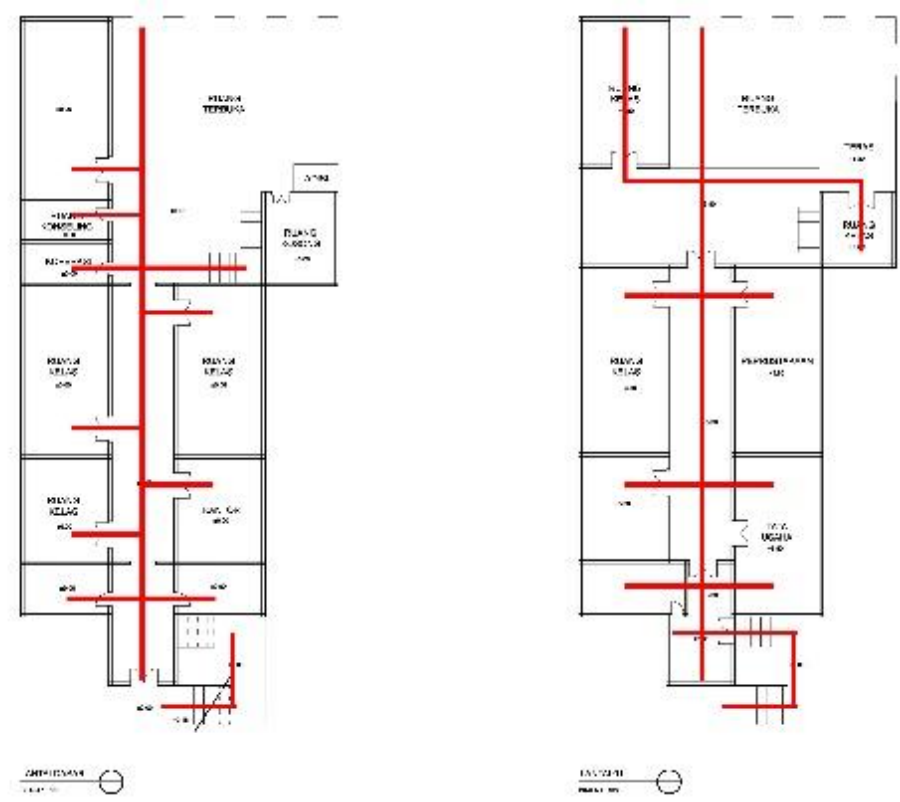

Figur 10. Jalur Sirkulasi Rumah Kaca

Tatanan rumah kaca. Rumah kaca memiliki sumbu tengah pada bangunan. Sumbu yang membaginya hingga menjadi dua bagian membuat rumah ini menjadi simetris. Pembagian ruang dari bangunan ini juga ikut menjadi simetris dan cukup seimbang. Selain itu, daun jendela serta pola kaca yang berada di lantai dua membentuk irama yang berulang dan berpola pada dinding rumah kaca. Pengulangan bentuk dan ornamen daun jendela serta kaca dilakukan secara linear dan konsisten. Repetisi ini berulang baik pada bagian depan maupun pada bagian samping rumah kaca dan membentuk karakteristik visual pada rumah kaca. Sedangkan rumah kaca tidak memiliki hirarki pada bangunan. Hal ini karena fungsi bangunan adalah fungsi madrasah, bukan hunian (rumah tinggal). Fungsi bangunan madrasah hanya digunakan untuk belajar dan mengajar, tidak ada kepentingan fungsi maupun ruang yang khusus. Dan datum pada rumah kaca adalah atap genteng yang memiliki bentuk atap pelana dengan kemiringan atap $45^{\circ}$.

Pembagian ruang rumah kaca. sudah tidak lagi menggunakan pembagian ruang rumah tinggal Islam. Hal ini dikarenakan fungsi bangunan yang sudah berganti menjadi fungsi bangunan madrasah, sehingga kebutuhan dan aktivitas di dalamnya berbeda dengan fungsi rumah tinggal. Kebutuhan aktivitas madrasah yang hanya seputar belajar dan mengajar serta pengguna bangunan yang lebih dominan pada anak-anak kelas 1 hingga kelas 6, membuat pembagian ruang pada rumah kaca seperti pembagian ruang madrasah pada umumnya. Untuk itu pembagian rumah kaca dibagi menjadi tiga zona, yaitu zona publik, zona semi privat dan zona privat. Pada lantai satu, zona publik merupakan ruang penerima. Ruang penerima ini berupa ruang tamu pada rumah kaca. Zona semi privat terdiri dari ruangruang kelas, dan ruang kantor. Dan pada zona privat terdiri dari ruang konseling dan ruang koperasi. Pada lantai dua rumah kaca, zona publik merupakan ruang penerima berupa ruang tamu. Dan zona semi privat terdiri dari ruang kelas, ruang rapat, perpustakaan dan ruang tata usaha. Pada lantai dua rumah kaca tidak terdapat zona privat.

\section{KESIMPULAN}

Berdasarkan hasil analisa dan sintesa pada bab sebelumnya, dapat diambil kesimpulan dari penelitian yang dilakukan dengan dasar pertanyaan di awal penelitian yaitu: 


\section{"Bagaimana bentuk, ruang dan tatanan rumah pada Kampung Arab Al-Munawar Palembang?"}

Analisa bentuk, ruang dan tatanan rumah pada Kampung Arab Al-Munawar Palembang diwakilkan oleh tiga objek penelitian. Tiga objek penelitian diambil berdasarkan pertimbangan keunikan latar belakang sejarah dari masing-masing bangunan. Objek penelitian dibagi menjadi hunian yaitu rumah darat dan rumah batu serta non hunian yaitu rumah kaca.

Bentuk dasar pada massa hunian rumah darat adalah persegi panjang yang mengalami substraksi. Faktor terciptanya bentuk dipengaruhi oleh faktor sosial budaya karena rumah ini mengadaptasi gaya arsitektur rumah limas Palembang, faktor iklim karena rumah darat merupakan tipologi rumah panggung dan faktor material dengan penggunaan material kayu ulin dengan mutu kayu sangat baik dan membuat rumah ini dapat berdiri hingga ratusan tahun. Sedangkan behavior setting rumah darat mengikuti dasar pola ruang berbatas tetap (Fixed Features Space) berupa dinding-dinding kayu yang melingkupi bangunan ini relatif tetap.

Ruang memiliki unsur pembentuk secara vertikal pada rumah darat yaitu empat bidang tertutup berupa dinding kayu pada bangunan dan secara horizontal adalah bidang dasar yang diangkat. Selain itu pintu masuk rumah darat diletakkan terpusat pada bidang depan bangunan dan terdapat juga pintu masuk pada bagian samping sebagai jalan perempuan untuk menuju ke dalam rumahnya. Pintu masuk samping ini menjadi ciri khas rumah tinggal Arab. Rumah darat memiliki konfigurasi jalur linear dan hubungan jalur ruang yang menembus ruang-ruang.

Prinsip penataan pada rumah darat berupa sumbu tengah pada bangunan yang membuat rumah ini menjadi simetris dan memberikan keseimbangan dalam bentuknya. Hirarki pada bangunan rumah darat adalah kekijing (lantai yang berundak setinggi $30 \mathrm{~cm}$ ) pada bagian depan bangunan. Terdapat juga jendela-jendela yang memiliki irama dan repetisisi berpola pada dinding samping rumah. Dan yang menjadi datum rumah darat adalah atap genteng. Selain itu, hunian rumah darat memiliki pembagian ruang seperti pada rumah tinggal Islam yaitu pembagiannya menjadi zona birun (zona publik) dan zona anderun (zona private) serta terdapat courtyard yang berfungsi untuk melindungi perempuan dalam melakukan aktivitas di dalam rumah tanpa terlihat oleh orang luar terutama laki-laki yang bukan muhrimnya.

Bentuk dasar pada massa hunian rumah batu adalah persegi panjang yang juga mengalami substraksi. Faktor terciptanya bentuk adalah faktor sosial budaya karena rumah in mengadaptasi gaya arsitektur Indis. Selain itu juga terdapat faktor material pada bangunan dengan menggunakan material batu dengan ketebalan $37 \mathrm{~cm}$ sebagai dinding rumah. Sedangkan behavior setting berdasarkan dasar pola ruang berbatas tetap berupa dinding batu dan ruang berbatas tidak tetap berupa dinding partisi.

Ruang memiliki unsur pembentuk secara vertikal pada rumah batu adalah empat bidang tertutup berupa dinding batu dan secara horizontal adalah bidang dasar yang diangkat. Selain itu pintu masuk rumah batu diletakkan terpusat pada bidang depan bangunan dan terdapat juga pintu masuk alternatif di bagian samping rumah yang pada masa sekarang pintu alternatif ini lebih sering digunakan daripada pintu masuk utama. Pintu masuk samping ini menjadi ciri khas rumah tinggal Arab. Rumah batu memiliki konfigurasi jalur yang linear dan hubungan jalur ruang yang menembus ruang-ruang.

Prinsip penataan pada rumah batu berupa sumbu tengah pada bangunan. Sumbu ini kemudian yang membuat bangunan menjadi simetris dan memberikan keseimbangan dalam bentuknya. Hirarki pada rumah batu adalah teras luar serta terdapat juga jendela yang mengalami repetisi berpola pada dinding samping rumah. Dan yang menjadi datum rumah 
batu adalah atap genteng. Selain itu, hunian rumah batu memiliki pembagian ruang seperti pada rumah tinggal Islam yaitu pembagiannya menjadi zona birun (zona publik) dan zona anderun (zona privat) serta terdapat courtyard yang berfungsi untuk melindungi perempuan dalam melakukan aktivitas di dalam rumah tanpa terlihat oleh orang luar terutama laki-laki yang bukan muhrimnya.

Massa non hunian rumah kaca berfungsi sebagai madrasah dengan bentuk dasar persegi panjang yang mengalami adisi. Faktor terciptanya bentuk faktor sosial budaya karena rumah ini menggunakan gaya arsitektur Indis. Selain itu juga terdapat faktor material yang menggunakan batu bata dan beton pada lantai dasar dan material kayu pada lantai satu. Sedangkan behavior setting berdasarkan dasar pola ruang berbatas tetap berupa dinding bata dan dinding kayu.

Ruang memiliki unsur pembentuk secara vertikal pada rumah kaca adalah empat bidang tertutup dan secara horizontal adalah adanya bidang dasar yang diangkat. Selain itu pintu masuk rumah kaca dibuat menjorok keluar dan terdapat juga pintu masuk alternatif pada bagian belakang bangunan. Hal ini dikarenakan fungsi bangunan rumah kaca sebelum menjadi madrasah adalah rumah tinggal. Rumah kaca juga memiliki konfigurasi jalur yang linear dan hubungan jalur ruang yang melalui ruang-ruang.

Prinsip penataan pada rumah kaca berupa sumbu tengah pada bangunan yang membuat rumah ini menjadi simetris dan cukup seimbang. Daun jendela serta pola kaca yang berada di lantai dua rumah kaca membentuk irama yang berulang dan berpola pada dinding rumah kaca. Dan pada rumah kaca tidak memiliki hirarki pada bangunan. Dan yang menjadi datum rumah kaca adalah atap genteng. Selain itu, pembagian ruang pada rumah kaca sudah tidak lagi menggunakan pembagian ruang rumah tinggal Islam karena fungsi bangunan yang sudah berganti menjadi fungsi madrasah. Sehingga, pembagiannya menjadi zona publik, zona semi privat dan zona privat serta terdapat courtyard pada bagian belakang bangunan.

Sehingga, dapat dikatakan bahwa persamaan dari ketiga objek penelitian ini adalah memiliki bentuk dasar persegi panjang yang mengalami adisi dan/ substraksi. Bentuk bangunan dipengaruhi oleh faktor sosial budaya, iklim dan material. Sedangkan ruang memiliki unsur pembentuk secara vertikal adalah empat bidang tertutup dan secara horizontal adalah bidang dasar yang diangkat. Pembagian ruang masih berdasarkan rumah tinggal Islam kecuali rumah kaca karena sudah berganti fungsi bangunan menjadi madrasah.

\section{DAFTAR PUSTAKA}

Alimansyur, Moh, dkk. Arsitektur Tradisional Daerah Sumatera Selatan. (Bandung: Direktur Jenderal Kebudayaan Departemen Pendidikan dan Budaya, 1990). 26-30.

Ayu, Elvira Putri. Perpaduan Langgam Arsitektur Rumah Tinggal di Kampung Arab Al-Munawar Palembang. (Bandung: Universitas Katolik Parahyangan, 2011). 14-15.

Ching, Francis D.K. Bentuk, Ruang dan Tatanan. Terjemahan Nurahma Tresani Hawadi (Jakarta: Erlangga, 2000). 38-155.

Fauziah, Meuthia Rizki. Bentuk, Ruang dan Tatanan Rumah pada Kampung Arab Al-Munawar di Tepi Sungai Musi Palembang. (Bandung: Universitas Katolik Parahyangan, 2011).

Ibnudin. 2017. Metode Penelitian | Pengertian, Tujuan, Macam, dan Metodologi Penelitian. https://ibnudin.net/metode-penelitian-metodologi-penelitian. Diakses pada 5 Februari 2018.

Malik, Sana dan Benish Mujahid. Perception of House Design in Islam: Experiences from Saudi Arabia and Pakistan. (Pakistan: University of Management and Technology Pakistan, 2016). 4-9.

Winnie, Satya. 2016. Kampung Arab Al-Munawar. http://www.satyawinnie.com/2016/02/kampungalmunawar-rekam-jejak-arab-di-palembang.html. Di akses pada 21 April 2018. 